\title{
Estimasi Emisi Gas Rumah Kaca dari Sapi Potong di Bangka Belitung
}

\section{(Estimation of Greenhouse Gas Emission from Beef Cattle in Bangka Belitung)}

\author{
Zuratih $^{1}$, Widiawati $\mathrm{Y}^{2}$ \\ ${ }^{1}$ Pusat Penelitian dan Pengembangan Peternakan, Badan Litbang Pertanian \\ ${ }^{2}$ Balai Penelitian Ternak, Ciawi Bogor \\ zuratih89@gmail.com
}

\begin{abstract}
In Bangka Belitung Province, the population of beef cattle has increased by $15 \%$ per year. The side effect is an increasing in greenhouse gas (GHG) emissions from beef cattle. To find out the policies and steps that can be taken to reduce this side effects is through inventory GHG emissions. The study aims to conduct GHG inventory from beef cattle to determine the contribution of GHG emissions from beef cattle. These results can be used as a basis for taking the next steps in GHG mitigation technique used from the livestock sector. In this GHG inventory process, primary data were body weight, temperature, manure management system and feed intake and secondary data used was beef cattle population. The calculation was undertaken by using Tier 2 method of IPCC 2006 and using the ALU Tool software, then the calculation results are presented in descriptive. The results showed that methane $\left(\mathrm{CH}_{4}\right)$ from enteric fermentation was the largest contributor to GHG, which was $8.675 \mathrm{Gg} \mathrm{CO}_{2}$-e / year, while $\mathrm{CH}_{4}$ from manure management contributed for only $0.303 \mathrm{Gg} \mathrm{CO}_{2}$-e / year. The $\mathrm{N}_{2} \mathrm{O}$ emissions, which are only released from manure management, contribute for about $0.092 \mathrm{Gg}$ $\mathrm{CO}_{2}$-e/year. Among the sub categories of beef cattle, adult cows (age $>4$ years) are the biggest contributors to enteric $\mathrm{CH}_{4}$, whereas $\mathrm{N}_{2} \mathrm{O}$ is more produced by fattening. It was concluded that the largest contributor of GHG emissions from beef cattle were from enteric fermentation (95.69\%), where sub category of adult cattle contribute for about $38.68 \%$. Emission of $\mathrm{N}_{2} \mathrm{O}$ were contributed by imported cattle going to fattening period (66.30\%).
\end{abstract}

Key words: Greenhouse gas emission, beef cattle, methane $\left(\mathrm{CH}_{4}\right)$ dinitrogen oxide $\left(\mathrm{N}_{2} \mathrm{O}\right)$, Bangka Belitung Province

\begin{abstract}
ABSTRAK
Di Provinsi Bangka Belitung, populasi sapi potong meningkat sebesar 15\% pertahunnya. Salah satu dampak sampingnya adalah peningkatan emisi gas rumah kaca (GRK) dari sapi potong. Untuk mengetahui kebijakan dan langkah yang dapat diambil untuk mengurangi dampak samping ini, maka perlu dilakukan inventory emisi GRK. Study ini bertujuan untuk melakukan inventory GRK dari sapi potong guna mengetahui sumbangan emisi GRK dari sapi potong. Hasil ini dapat digunakan sebagai dasar untuk mengambil langkah selanjutnya dalam upaya mitigasi GRK dari sektor peternakan. Dalam proses inventory GRK ini digunakan data primer berupa bobot badan, temperature, sistem pengelolaan kotoran dan konsumsi pakan, sedangkan data sekunder berupa populasi sapi potong. Penghitungan dilakukan dengan menggunakan metode Tier 2 IPCC 2006 dengan bantuan software ALU Tool, selanjutnya hasil penghitungan disajikan dalam bentuk deskriptif. Hasil menunjukkan bahwa $\mathrm{CH}_{4}$ dari fermentasi enterik merupakan penyumbang terbesar GRK dari sapi potong yaitu sebesar 8,675 $\mathrm{Gg} \mathrm{CO}_{2}$-e/tahun, sedangkan $\mathrm{CH}_{4}$ dari kotoran ternak menyumbang sebesar
\end{abstract}


0,303 $\mathrm{Gg} \mathrm{CO}_{2}$-e/tahun. Emisi $\mathrm{N}_{2} \mathrm{O}$ yang hanya dikeluarkan dari proses pengelolaan kotoran ternak menyumbang sebesar 0,092 $\mathrm{Gg} \mathrm{CO}_{2}$-e/tahun. Diantara sub kategori sapi potong, maka sapi dewasa (umur $>4$ tahun) merupakan penyumbang $\mathrm{CH}_{4}$ enterik terbesar, sedangkan $\mathrm{N}_{2} \mathrm{O}$ lebih banyak dihasilkan dari sapi potong yang digemukkan (fattening). Disimpulkan bahwa emisi GRK terbesar dari ternak sapi potong adalah dari fermentasi enterik (95,69\%), dimana sub kategori sapi dewasa menyumbang sebesar 38,68\%. Emisi $\mathrm{N}_{2} \mathrm{O}$ dari pengelolaan kotoran terbesar yaitu 66,30\% disumbang dari kotoran sapi impor atau yang digemukkan (fattening).

Kata kunci: Gas rumah kaca (GRK), metana $\left(\mathrm{CH}_{4}\right)$, dinitro oxide $\left(\mathrm{N}_{2} \mathrm{O}\right)$, sapi potong, Bangka Belitung

\section{PENDAHULUAN}

Provinsi Kepulauan Bangka Belitung mempunyai luas wilayah daratan 16.424,14 $\mathrm{km}^{2}$ yang terdiri dari dua pulau besar yaitu Pulau Bangka dan Pulau Belitung, serta dikelilingi beberapa pulau kecil di sekitarnya. Suhu minimum rata-rata mencapai $23^{\circ} \mathrm{C}$ pada bulan Pebruari dan suhu maksimum mencapai $33^{\circ} \mathrm{C}$ pada bulan Oktober, dengan kelembaban udara rata-rata $75 \%$ hingga $88 \%$, sedangkan curah hujan berkisar antara $1.500 \mathrm{~mm}$ sampai $2.000 \mathrm{~mm}$ per tahun. Dalam satu tahun, sepanjang bulan curah hujan juga relatif tinggi, kecuali pada bulan Agustus, September, dan Oktober yang relatif kering (BPS Babel 2019).

Komoditas andalannya adalah lada, namun beberapa tahun belakangan, komoditas ini digeser oleh kelapa sawit yang semakin luas penanamannya. Berdasarkan kondisi pedo-agroklimatnya, maka sektor pertanian mempunyai peluang untuk dikembangkan. Dibidang peternakan, populasi ternak ruminansia terutama sapi belum mencukupi untuk keperluan daerah ini. Sepanjang waktu sapi didatangkan dari luar daerah untuk mencukupi kebutuhan daging penduduk. Namun sejak tahun 2003 populasi sapi meningkat tajam karena banyaknya bantuan sapi dan masuknya sapi-sapi dari luar daerah. Jika pada tahun 2000 populasi sapi hanya 3.511 ekor, maka pada tahun 2018 menjadi 13.276 ekor atau terjadi kenaikan sebanyak 15\% per tahunnya (Ditjen PKH 2018). Peningkatan ini akan terus berlangsung untuk dapat memenuhi kebutuhan daging sapi di Provinsi tersebut.

Selain itu, pengembangan sapi potong didukung oleh agroklimat yang sangat sesuai dan menguntungkan untuk pertumbuhan rumput dan hijauan makanan ternak. Adanya pengembangan perkebunan sawit menjadi salah satu keuntungan dalam upaya penyediaan bahan pakan sapi potong. Dengan demikian masalah pakan tidak menjadi kendala pengembangan sapi. Dari data yang tersedia, masih terdapat 7.847 ha padang rumput (padang penggembalaan) dan 82.952 ha lahan yang tidak diusahakan. Selain itu, peluang pengembangan rumput dan hijauan makanan ternak dapat diupayakan di pekarangan (22.444 ha), ladang/tegalan (34.792 ha), dan areal perkebunan (161.840 ha).

Adanya peningkatan populasi sapi yang cukup besar, tentunya dapat mendorong terjadinya emisi gas rumah kaca (GRK) khususnya dari sektor peternakan. Sebagaimana diketahui bahwa sapi potong merupakan penyumbang terbesar emisi GRK diantara jenis ternak lainnya (Widiawati et al. 2016). Emisi GRK dari sapi potong bersumber dari sistem pencernaan yang disebut dengan enteric fermentasi berupa gas metana $\left(\mathrm{CH}_{4}\right)$ dan bersumber dari pengelolaan kotoran ternak berupa $\mathrm{CH}_{4}$ dan dinitrogen oxide $\left(\mathrm{N}_{2} \mathrm{O}\right)$ (Rong-Zhen et al. 2016).

Guna mengetahui besarnya emisi GRK yang dikeluarkan oleh sapi potong, yang selanjutnya juga dapat digunakan sebagai dasar untuk menyusun kebijakan dan strategi untuk memitigasi emisi GRK, maka diperlukan aktivitas inventory emisi GRK dari sektor 
peternakan. Study yang telah dilakukan bertujuan untuk melakukan inventory GRK dari sapi potong di wilayah Bangka Belitung dengan menggunakan software terbaru yaitu ALU Tool Software.

\section{MATERI DAN METODE}

Inventory GRK dilakukan dengan menggunakan metode Tier 2 dari buku panduan IPCC (IPCC 2006). Pada metode ini digunakan data berupa data primer yaitu populasi ternak/sapi yang sudah dikategorikan berdasarkan umur/status produksi dan data faktor emisi (FE). Nilai FE yang tertera dalam buku IPCC 2006 merupakan default factor untuk wilayah Asia. Penggunaan default factor tersebut untuk inventory GRK di Indonesia menjadi kurang tepat mengingat adanya perbedaan jenis dan tipe sapi potong dan pakan yang diberikan. Oleh karena itu pada studi ini digunakan FE lokal Indonesia (Widiawati et al. 2016). Data sekunder lainnya digunakan yaitu berupa temperatur lingkungan, konsumsi pakan dan bobot badan ternak.

\section{Data primer}

Data yang dimaksud adalah terkait lingkungan dan sistem pengelolaan kotoran ternak yang dilakukan para peternak di Bangka Belitung. Dengan asumsi bahwa semua kotoran sapi potong untuk penggemukan disimpan dalam bentuk kering dan dicampur dangan bahan lain (solid storage). Sedangkan ternak di sub kategori lainnya diasumsikan $50 \%$ ternak dikandangkan sehingga kotoran berupa solid storage dan 50\% lainnya digembalakan sehingga dikategorikan disebar secara langsung ke lapangan (pasture/range). Selanjutnya tempertaur di wilayah Bangka Belitung diatas $28^{\circ} \mathrm{C}$ atau tergolong suhu hangat.

\section{Data sekunder}

Data sekunder berupa populasi sapi potong tahun 2017 diambil dari Buku Statistik Peternakan Provinsi Bangka Belitung (Ditjen PKH 2018). Nilai FE lokal Indonesia untuk sapi potong berdasarkan hasil penelitian Widiawati et al. (2016). Populasi sapi potong berdasarkan sub kategori dan nilai FE lokal Indonesia untuk sapi potong disajikan pada Tabel 1.

\section{Metode penghitungan}

Penghitungan emisi GRK dari sapi potong ini dilakukan dengan menggunakan ALU Tool software yang dikeluarkan oleh IPCC (IPCC 2006). Cara kerja software ini adalah memasukkan semua data primer dan sekunder yang diperlukan sesuai format didalam software, sehingga dihasilkan data emisi untuk metana $\left(\mathrm{CH}_{4}\right)$ dari enteric fermentasi dan pengelolaan kotoran, serta $\mathrm{N}_{2} \mathrm{O}$ dari pengelolaan kotoran. Data disajikan secara deskriptif untuk menggambarkan situasi emisi GRK di wilayah Bangka Belitung. 
Tabel 1. Data populasi sapi potong berdasarkan sub kategori pada tahun 2017 di Provinsi Kepulauan Bangka Belitung dan nilai faktor emisi

\begin{tabular}{|c|c|c|c|c|}
\hline \multirow[t]{2}{*}{ Sub kategori } & \multirow{2}{*}{$\begin{array}{l}\text { Populasi } \\
\text { (ekor) }^{*}\end{array}$} & \multirow{2}{*}{$\begin{array}{l}\text { Faktor emisi enteric } \\
\text { (kg CH}_{4} / \text { tahun/ekor) }\end{array}$} & \multicolumn{2}{|c|}{$\begin{array}{c}\text { Faktor emisi } \mathrm{CH}_{4} \\
\text { pengelolaan kotoran } \\
\text { (kg CH}_{4} / \text { tahun/ekor) }\end{array}$} \\
\hline & & & $\begin{array}{l}\text { Solid } \\
\text { storage }\end{array}$ & $\begin{array}{c}\text { Pasture/rang } \\
\text { e/paddock }\end{array}$ \\
\hline \multicolumn{5}{|l|}{ Sapi potong } \\
\hline Anak (0-1 tahun) & 2.315 & 18,18 & 0,114 & 0,410 \\
\hline Pertumbuhan (1-2 tahun) & 1.268 & 27,18 & 0,202 & 0,727 \\
\hline Muda (2-4 tahun) & 1.819 & 41,77 & 0,240 & 0,864 \\
\hline Dewasa ( $>4$ tahun) & 2.473 & 55,89 & 0,329 & 1,183 \\
\hline Imported (fattening) & 4.768 & 25,49 & 2,172 & - \\
\hline
\end{tabular}

Sumber: * Ditjen PKH (2018); ** Widiawati et. al. (2016); *** IPCC (2006)

\section{HASIL DAN PEMBAHASAN}

Data hasil penghitungan dengan menggunakan ALU Tool software dikemas dalam 4 tabel (Tabel 2 sampai Tabel 5). Emisi gas $\mathrm{CH}_{4}$ dari fermentasi enterik yang disajikan pada Tabel 2 mengindikasikan bahwa emisi $\mathrm{CH} 4$ terbesar dihasilkan oleh sapi potong dewasa (>4 tahun), atau sekitar 2,87 kali jauh lebih besar dibandingkan dengan emisi yang dikeluarkan oleh sapi yang diimport dan dikelola untuk penggemukan. Dari data populasi, sapi dalam sub kategori imported atau penggemukan ini berjumlah hampir 2 kali lipat populasi sapi dalam sub kategori dewasa. Namun jika diamati dari nilai faktor emisi yaitu jumlah emisi $\mathrm{CH}_{4}$ per tahun yang dikeluarkan oleh setiap ekor ternak, menunjukkan bahwa sapi dewasa mengeluarkan emisi $\mathrm{CH}_{4}$ lebih besar (2,2 kali) dibandingkan sapi imported.

Tabel 2. Estimasi emisi $\mathrm{CH}_{4}$ dari fermentasi enterik sapi potong di Provinsi Kepulauan Bangka Belitung Tahun 2017 yang dihitung dengan menggunakan ALU Tool Software

\begin{tabular}{lcc}
\hline \hline \multirow{2}{*}{ Sub kategori } & \multicolumn{2}{c}{ Emisi CH $_{4}$} \\
\cline { 2 - 3 } & $\left(\mathrm{Gg} \mathrm{CH}_{4} /\right.$ tahun $)$ & $\left(\mathrm{Gg} \mathrm{CO}_{2}\right.$-e/tahun $)$ \\
\hline Import (penggemukan) & 0,057 & 1,420 \\
Dewasa (>4 tahun) & 0,136 & 3,390 \\
Anak (0-1 tahun) & 0,043 & 1,085 \\
Pertumbuhan (1-2 tahun) & 0,042 & 1,048 \\
Muda (2-4 tahun) & 0,073 & 1,823 \\
\hline Total & 0,351 & 8,765 \\
\hline
\end{tabular}

Perbedaan emisi $\mathrm{CH}_{4}$ dari enterik antara sapi dewasa dan imported/penggemukan lebih disebabkan karena adanya perebedaan jenis pakan yang dikonsumsi. Seperti yang 
dilaporkan oleh Hammond et al. (2013); Gregorini et al. (2010); dan Dijkstra et al. (2011), bahwa jumlah emisi $\mathrm{CH}_{4}$ yang diproduksi selama proses fermentasi makanan dalam rumen tergantung pada kualitas pakan khususnya kandungan energi dan serat kasar, serta jumlah yang dikonsumsinya. Peningkatan konsumsi sebagai akibat dari peningkatan kualitas pakan menghasilkan tingkat kecernaan yang baik, sehingga dihasilkan emisi $\mathrm{CH}_{4}$ yang rendah. Sapi yang dipelihara untuk penggemukan pada umumnya diberi pakan dengan komposisi konsentrat $>60 \%$ dari total ransum, sehingga memiliki daya cerna yang lebih baik dibandingkan dengan pakan yang biasanya diberikan pada sapi yang dipelihara oleh peternak rakyat (Permana 2015). Emisi $\mathrm{CH}_{4}$ dari sub kategori anak masih lebih rendah dibandingkan dengan dari sub kategori dewasa, meskipun populasi keduanya relatif sama. Hal ini disebabkan karena sapi pada level produksi anak (umur 0-1 tahun) tingkat konsumsi hijauannya masih rendah.

Terdapat dua jenis pengelolaan kotoran ternak, yaitu solid storage dan pasture/range/paddock. Solid storage dikategorikan pengelolaan kotoran untuk sapi yang dikandangkan sepanjang hari, dimana kotoran ditumpuk beberapa hari sebelum dibersihkan. Pengelolaan kotoran pasture/range/paddock adalah kotoran yang dikeluarkan oleh sapi yang dipelihara dilepas atau digembalakan. Pada sistem ini maka kotoran langsung tersebar di lapangan/padang rumput. Hasil estimasi emisi $\mathrm{CH}_{4}$ yang dihasilkan dari kedua sistem pengelolaan kotoran disajikan pada Tabel 3. Hasil menunjukkan bahwa jumlah $\mathrm{CH}_{4}$ yang dihasilkan dalam sistem pengelolaan kotoran pasture/range/paddock lebih besar jika dibandingkan dengan kotoran yang dikelola dalam bentuk solid. Hal ini disebabkan nilai faktor emisi untuk kotoran yang di paddock/range atau penggembalaan tercatat 3,6 kali lebih besar daripada yang dikelola dalam bentuk solid storage seperti yang disajikan dalam buku panduan IPCC (2006) (Tabel 1). Selain itu, kotoran yang disimpan dalam bentuk solid yaitu penyimpanan dalam bentuk kering dan terbuka akan berada dalam kondisi aerob, sehingga lebih sedikit gas $\mathrm{CH}_{4}$ yang terbentuk (EPA 2010).

Tabel 3. Estimasi emisi $\mathrm{CH}_{4}$ dari pengelolaan kotoran sapi potong berdasarkan model pengelolaan kotoran sapi di Provinsi Bangka Belitung Tahun 2017 yang dihitung dengan menggunakan ALU Tool Software

\begin{tabular}{llcc}
\hline \hline \multirow{2}{*}{ Sub kategori } & Pengelolaan kotoran & Emisi CH & Emisi CH $_{4}$ \\
\cline { 3 - 4 } & & $\left(\mathrm{Gg} \mathrm{CH}_{4} /\right.$ tahun $)$ & $\left(\mathrm{Gg} \mathrm{CO}_{2}\right.$-e/tahun $)$ \\
\hline Impor (penggemukan) & Solid storage & 0,004 & 0,090 \\
Dewasa (>4 tahun) & Pasture/range/paddock & 0,003 & 0,078 \\
Dewasa (>4 tahun) & Solid storage & 0,001 & 0,023 \\
Anak (0-1 tahun) & Pasture/range/paddock & 0,001 & 0,023 \\
Anak (0-1 tahun) & Solid storage & 0,000 & 0,008 \\
Pertumbuhan (1-2 tahun) & Pasture/range/paddock & 0,001 & 0,023 \\
Pertumbuhan (1-2 tahun) & Solid storage & 0,000 & 0,006 \\
Muda (2-4 tahun) & Pasture/range/paddock & 0,002 & 0,043 \\
Muda (2-4 tahun) & Solid storage & 0,001 & 0,013 \\
\hline Total & & 0,012 & 0,303 \\
\hline
\end{tabular}

Gas $\mathrm{N}_{2} \mathrm{O}$ hanya diemisikan dari proses peengelolaan kotoran ternak saja. Hasil penghitungan pada Tabel 4 menunjukkan bahwa $\mathrm{N}_{2} \mathrm{O}$ dikeluarkan hanya dari kotoran 
ternak yang dikelola dalam bentuk solid storage. Diantara ke lima sub kategori, maka sapi yang dipeliharan secara intensif dalam kandang (sub kategori imported/fettening) mengeluarkan lebih banyak $\mathrm{N}_{2} \mathrm{O}$ dibandingkan dengan sub kategori lainnya atau 5,1 kali lebih banyak dibandingkan dengan sub kategori sapi dewasa dan 15,25 kali jika dibandingkan dengan sapi dalam sub kategori muda.

Tabel 4. Estimasi emisi $\mathrm{N}_{2} \mathrm{O}$ kotoran ternak sapi potong di Provinsi Bangka Belitung Tahun 2017 yang dihitung dengan menggunakan ALU Tool Software

\begin{tabular}{llcc}
\hline \multirow{2}{*}{ Sub kategori } & \multirow{2}{*}{$\begin{array}{l}\text { Pengelolaan } \\
\text { kotoran }\end{array}$} & Emisi N $_{2} \mathrm{O}$ & Emisi N $\mathrm{O}$ \\
\cline { 3 - 4 } & & $\left(\mathrm{kg} \mathrm{N}_{2} \mathrm{O} /\right.$ tahun $)$ & $\left(\mathrm{Gg} \mathrm{CO}_{2}\right.$-e/tahun $)$ \\
\hline Import (penggemukan) & Solid storage & 204,358 & 0,061 \\
Dewasa (>4 tahun) & Solid storage & 48,789 & 0,015 \\
Anak betina (0-1 tahun) & Solid storage & 15,599 & 0,005 \\
Pertumbuhan (1-2 tahun) & Solid storage & 15,061 & 0,004 \\
Muda (2-4 tahun) & Solid storage & 26,207 & 0,008 \\
\hline Total & & 310,013 & 0,092 \\
\hline
\end{tabular}

Banyaknya $\mathrm{N}_{2} \mathrm{O}$ yang diemisikan dari kotoran ternak sangat tergantung pada jumlah pakan yang dikonsumsi dan kandungan nitrogen/protein dari pakan (Olander et al. 2013; Gupta et al. 2007), semakin tinggi konsumsi dan kandungan protein dalam pakan, maka semakin besar emisi $\mathrm{N}_{2} \mathrm{O}$ dari kotoran. Sapi yang dipelihara untuk penggemukan umumnya diberi pakan dengan jumlah besar untuk meningkatkan pertambahan bobot badan hariannya. Selain itu pakan yang diberikan pada periode penggemukan (umumnya 3-4 bulan) biasanya berkualitas lebih baik dibandingkan dengan sapi-sapi yang dipelihara dalam jangka panjang.

Total emisi GRK dari sapi potong di Provinsi Babel tahun 2017 disajikan pada Tabel 5. Total emisi merupakan penjumlahan emisi $\mathrm{CH}_{4}$ dari enteric fermentasi dan pengelolaan kotoran dan $\mathrm{N}_{2} \mathrm{O}$ dari pengelolaan kotoran. Emisi $\mathrm{CH}_{4}$ dari enteric fermentasi sapi potong merupakan 95,69\% dari total emisi GRK sapi potong selama satu tahun. 3,31\% adalah emisi $\mathrm{CH}_{4}$ dari pengelolaan kotoran dan hanya $1 \%$ berupa emisi $\mathrm{N}_{2} \mathrm{O}$ dari pengelolaan kotoran. Berdasarkan hasil ini dapat diketahui bahwa fermentasi enterik merupakan faktor utama dari emisi GRK. Sehingga kebijakan yang dapat diambil oleh pemerintah daerah dalam upaya mengurangi emisi GRK dari peternakan adalah melalui pengurangan/mitigasi emisi $\mathrm{CH}_{4}$ dari fermentasi enterik. Hal ini dapat dilakukan melalui berbagai cara yaitu memperbaiki kualitas pakan yang diberikan kepada ternak, memperbaiki sistem pencernaan melalui manipulasi sistem fermentasi dalam rumen. Manipulasi kinerja mikriba dalam proses fermentasi rumen dapat dilakukan melalui pemberian pakan adtitif berupa probiotik atau mineral (Martin et al. 2010; Widiawati 2013; Thalib et al. 2010). 
Tabel 5. Total estimasi emisi GRK dari sapi potong di Provinsi Bangka Belitung Tahun 2017 yang dihitung dengan menggunakan ALU Tool Software

\begin{tabular}{lccc}
\hline \hline \multirow{2}{*}{ Sumber emisi } & Emisi CH $_{4}$ & Emisi N & $\mathrm{O}$ \\
\cline { 2 - 4 } & $\left(\mathrm{Gg} \mathrm{CO}_{2}\right.$-e/tahun $)$ & $\left(\mathrm{Gg} \mathrm{CO}_{2}\right.$-e/tahun $)$ & $\left(\mathrm{Gg} \mathrm{CO}_{2}\right.$-e/tahun $)$ \\
\hline Fermentasi rnterik & 8,765 & $\mathrm{NA}$ & 8,765 \\
Pengelolaan kotoran & 0,303 & 0,092 & 0,395 \\
\hline Total & 9,068 & 0,092 & 9,160 \\
\hline
\end{tabular}

\section{KESIMPULAN}

Disimpulkan bahwa di provinsi Bangka Belitung emisi GRK terbesar dari ternak sapi potong adalah dari enteric fermentasi sebesar 95,69\%, dimana sub kategori sapi dewasa menyumbang sebesar 38,68\%. Emisi $\mathrm{N}_{2} \mathrm{O}$ dari pengelolaan kotoran terbesar yaitu 66,30\% disumbang dari kotoran sapi imported atau yang digemukkan (fattening).

Disarankan bahwa kebijakan pemerintah dalam mendukung penurunan emisi GRK adalah melalui teknik mitigasi untuk enteric fermentasi. Mitigasi ini dapat melalui perbaikan kualitas pakan maupun pemberian pakan aditif yang dapat merubah kinerja mikroba rumen dalam memfermentasi pakan dalam rumen.

\section{DAFTAR PUSTAKA}

[BPS Babel] Badan Pusat Statistik Bangka Belitung. 2019. Kondisi geografi dan iklim di Kepulauan Bangka Belitung [Internet]. [disitasi 22 Juli 2019]. Tersedia dari: https://babel.bps.go.id/.

Dijkstra J, Oenema O, Bannink A. 2011. Dietary strategies to reducing N excretion from cattle: implications for methane emissions. Curr Opin Environ Sustain. 3:414-422.

[Ditjen PKH] Direktorat Jenderal Peternakan dan Kesehatan Hewan. 2018. Statistik peternakan dan kesehatan hewan [Internet]. [disitasi 17 Mei 2019]. Tersedia dari: http://ditjennak.pertanian.go.id.

[EPA] Environmental Protection Agency. 2010. Inventory of U.S. greenhouse gas emissions and sinks: 1990-2008. Washington DC (USA): U.S. Environmental Protection Agency.

Gregorini P, Beukes P, Bryant R, Romera A. 2010. A brief overview and simulation of the effects of some feeding strategies on nitrogen excretion and enteric methane emission from grazing dairy cows. In: Edwards GR, Bryant R, editors. Proceedings of the 4th Australasian Dairy Science Symposium. Lincoln (Australia): Caxton Press. p. 29-43.

Gupta P.K, Jha A.K, Koul S, Sharma P, Prdhan V, Gupta V, Sharma C, Singh N. 2007. Methane and nitrous oxide emission from bovine manure management practices in India. Environ Pollut. 146:219-224.

Hammond KJ, Burke JL, Koolaard JP, Muetzel S, Pinares-Patino CS, Waghorn GC. 2013. The effect of feed intake on enteric methane emissions from sheep fed fresh white clover (Trifoliumrepens) and perennial ryegrass (Loliumperenne) forages. Anim Feed Sci Technol. 179:121-132.

[IPCC] Intergovernmental Panel on Climate Change. 2006. IPCC guidelines for national greenhouse gas inventories, prepared by the national greenhouse gas inventories programme. Eggleston HS, Buendia L, Miwa K, Ngara T, Tanabe K, editors. Kanalawa (Japan): Institute for Global Environmental Strategies. 
Martin C, Doreau M, Morgavi DP. 2010. Methane mitigation in ruminants: From rumen microbes to the animal. Animal. 4:351-365.

Olander, Wollenberg E, Tubiello F, Herold M. 2013. Advancing agricultural greenhouse gas quantification. Environ Res Lett. 8:7. doi: 10.1088/1748-9326/8/1/011002.

Permana H, Chuzaemi S, Marjuki, Mariyono. 2015. The effect of different crude fiber on feed intake, digestibility and VFA characteristic in the Ongole crossbred cattle [Internet]. [disitasi 5 September 2019]. Tersedia dari: https://fapet.ub.ac.id/wpcontent/uploads/2015/04/.

Rong-Zhen Z, Fang Y, Sun HX, Wang M, Zou DW. 2016. Rumen methane output and fermentation characteristics of gramineous forage and leguminous forage at differing harvest dates determined using an in vitro gas production technique. J Integr Agric. 15:414-423.

Thalib A, Widiawati Y, Haryanto B. 2010. Penggunaan complete rumen modifier (CRM) pada ternak domba yang diberi hijauan pakan berserat tinggi. JITV. 15:97-104.

Widiawati Y. 2013. Current and future mitigation activities on metane emission from ruminants in Indonesia. Paper in International Workshop on Inventory Data and Mitigation of Carbon and Nitrogen Cycling From Livestock in Indonesia. Jakarta, 24th April 2013.

Widiawati Y, Rofiq MN, Tiesnamurti B. 2016. Methane emission factors for enteric fermentation in beef cattle using IPCC Tier-2 method in Indonesia. JITV. 21:101-111. doi: http://dx.doi.org/10.14334/jitv.v21i2.1358. 